\title{
Abstracts of Papers Presented at the 2014 Annual Meeting
}

\author{
SESSION 1: POLITICAL ECONOMY: THE GREAT DEPRESSION
}

\author{
Stagflation in the 1930s: Why Did the French New Deal Fail
}

Most countries started to recover from the Great Depression when they devalued. France did not. In 1936, France left the Gold Standard and enacted New-Deal-style policies, including wage increases and a 40-hour week law. Stagflation followed; prices rose rapidly from 1936 to 1938 while output stagnated. We attempt to understand this anomalous experience and to draw inferences about the effectiveness of New-Deal-style policies in the 1930s. Using industry-level data, we explore whether hours restrictions can explain French stagnation. Finally, we construct a model to show how supply-side policies could have lowered output despite excess capacity.

Jeremie Cohen-Setton, University of California, Berkeley, Joshua K. Hausman, Ford School of Public Policy, and Johannes F. Wieland, University of California, San Diego

Inflation Expectations and Recovery from the Depression in 1933: Evidence from the Narrative Record

This paper uses the historical narrative record to identify whether inflation expectations shifted during the second quarter of 1933, precisely as the recovery from the Great Depression took hold. The paper has three main findings: (1) inflation expectations changed dramatically during the second quarter of 1933; (2) Roosevelt's communications strategy, primarily his public commitment to raise prices to pre-depression levels, along with key actions such as abandoning the gold standard, caused the shift in inflation expectations; and (3) monthly output growth increased by 4 to 7 percentage points as a result of the shift in expectations.

Andrew JaLIL, Occidental College, and Gisele RuA, Federal Reserve Board of Governors

\section{The Financial Interconnectedness of Railroads and the Transmission of Financial Distress During the Great Depression}

This paper studies the systemic importance of railroads through the widespread holdings of their bonds by American fiduciary institutions during the Great Depression. We examine the impact of a series of large railroad bond prices shocks using a remarkable data set of the individual bonds held by each Massachusetts savings bank annually. We suggest that the shocks varied across banks for reasons that are largely random relative to the other factors affecting these banks businesses, first because strict regulation prevented bank managers from gambling on particularly risky bonds, and second because the railroads were located outside of Massachusetts. The results suggest that 
the bond price declines caused banks to engage in greater contraction of their real estate loans, especially if they were also experiencing liquidity problems from deposit withdrawals.

Jonathan Rose, Federal Reserve Board of Governors, and EgOn ZakrajseK, Federal Reserve Board of Governors

\section{SESSION 2: HEALTH AND WELFARE}

\section{Adoption and Adult Outcomes in the Early Twentieth Century}

Modern research has found strong links between family structure and children's outcomes. One of the robust findings is that stepchildren and adopted children have worse adult outcomes compared to biological children. However, we know very little about how non-biological children fared historically. In this study, by linking adopted children across U.S. federal censuses in the first half of the twentieth century, we create a new dataset that contains rich information on both their childhood households and adult outcomes. To control for household heterogeneity, we also follow (non-adopted) siblings of adopted children into their adulthood. This unique dataset enables us to compare the long-run outcomes of adopted children and biological children controlling for observable and unobservable household characteristics. Our preliminary analysis suggests that educational attainment, income, and marriage patterns of adopted children differed significantly from non-adopted children. Overall, our study brings new historical evidence to the research on family structure.

Moriguchi, Chiaki, Hitotsubashi University, and John Parman, College of William and Mary

\section{The Dust Was Long in Settling: Human Capital and the Lasting Impact of the American Dust Bowl}

I use variation in childhood exposure to the Dust Bowl as a natural experiment to explain variation in adult human capital. I find that the Dust Bowl produced significant adverse impacts in later life, especially when exposure was in utero, increasing poverty and disability, and decreasing fertility and college completion. Agriculture-dependence exacerbates these effects, suggesting the shock was most damaging via the destruction of farming livelihoods. This agricultural collapse, however, had the positive effect of reducing demand for child farm labor and thus decreasing the opportunity costs of secondary schooling, as evidenced by increases in high school completion amongst the exposed.

\section{Vellore ARthi, University of Oxford}

\section{The Transition to Modern Health for New Zealand's Māori and Pākehā}

We analyze physical well-being among New Zealand Maori from first European contact to the late twentieth century. After colonial settlement Māori stature declined slowly. By the late nineteenth century Māori and Pākehā (NZ-born European descendents) statures were comparable. The twentieth century stature increase began in the 
1920s for Pākehā and 1950s for Māori. Convergence since the 1970s has re-established comparable stature. The early twentieth century convergence reflects cumulative land loss, disease incidence, rural-urban migration, and labour market segregation. The late twentieth century convergence reflects improvements in socio-economic status and health policy; it augurs well for later-life health of recently-born Māori.

KRIS INwOOD, University of Guelph, Les OXLEY, University of Wakaito, and Evan RoBerTs, University of Minnesota

\section{SESSION 3: DEBT, WEALTH, AND PENSIONS}

IN THE LONG NINETEENTH CENTURY

\section{Do Markets Reward Constitutional Reform? Lessons from America's State Debt Crisis}

America's state debt crisis presents a unique opportunity to identify whether institutional constraints lower borrowing costs. After nine states defaulted, 16 states adopted constitutional provisions promoting credibility. Only states that defaulted during the crisis were rewarded with lower borrowing costs and increased access to credit following reform. This cannot be explained by underlying trends or differences in the content of the reforms. Non-defaulting states, which had established commitment by avoiding default, were not rewarded because reform did not convey new information. These results indicate that sovereigns with tarnished reputations can benefit from adopting constitutional constraints to convey commitment.

BRIAN BEACH, University of Pittsburgh

Wealth Levels and Distribution in the Early American Republic, 1785-1815

This paper uses a comprehensive survey of property tax records to test Peter Lindert and Jeffrey Williamson's wealth estimates for the Early American Republic. The study measures changes in wealth levels and wealth distribution for more than 30,000 taxpayers at ten-year intervals between 1785 and 1815 , and presents preliminary results from my dissertation. The study confirms Lindert and Williamson's conclusion that national real wealth fell between 1785 and 1795, but argues that wealth levels rose significantly between 1795 and 1815 . Wealth distribution grew more unequal with each successive decade, but wealth levels and wealth distribution exhibited significant regional variation.

Frank GaRmon JR., University of Virginia

Patronage Politics and the Development of the Welfare State: Confederate Pensions in the American South

Beginning in the 1880 s, southern states introduced pensions for Confederate veterans and widows. They continued to expand these programs through the 1910s and 1920s, while states outside the region were introducing cash transfer programs for workers, poor mothers, and the elderly. We explore why southern states prioritized Confederate pensions over other aid to the poor. Using legislative documents, application records for 
Confederate pensions, and county-level census and electoral data, we argue that political considerations guided the enactment and distribution of these pensions. Confederate pensions programs aimed to increase support for Democratic candidates in poor, rural areas of the South.

SHARI Eli, University of Toronto, and Laura Salisbury, York University

\section{SESSION 4: CITIES}

\section{Zoning and Urban Persistence}

This paper investigates whether zoning has a long-term impact on the location of economic activity in cities. Using the introduction of comprehensive zoning in Chicago in 1923 along with a detailed map of pre-zoning land uses, we show that the initial zoning ordinance had an economically large impact on the location of industry, TRI facilities, commerce, and residential neighborhoods in 2005. Our results are robust to a series of border identification exercises using only blocks within a short range of both commercial and industrial zoning, suggesting our results are likely not driven by unobserved path dependence in land use that is correlated with the zoning ordinance. Finally, we assess the heterogeneous impact of zoning in areas of Chicago that were developed by 1923 and in areas of the city that were undeveloped but still subject to zoning.

AlLison SHerTzer, University of Pittsburgh and NBER, TATE Twinam, University of Pittsburgh, and

RANDall WaLSh, University of Pittsburg and NBER

\section{Creative Destruction: Barriers to Urban Growth and the Great Boston Fire of 1872}

Historical city growth, in the United States and worldwide, has required remarkable transformation of outdated durable structures. Private land-use decisions may generate persistent inefficiencies, however, due to externalities and various rigidities. This paper analyzes new plot-level data in the aftermath of the Great Boston Fire of 1872, estimating substantial economic gains from the opportunity for urban redevelopment in rapidly growing areas. An important mechanism appears to be positive externalities from neighbors' reconstruction. Strikingly, gains from this opportunity for urban redevelopment were sufficiently large that increases in land values were comparable to the value of all burned buildings.

Richard HornBeck, Harvard University and University of Chicago

Impact of Migration on Infant Health: Evidence from the Great Migration

The Great Migration of African Americans entailed a significant change in the health environment of infants during a time when access to medical care and public health infrastructure became increasingly important. We create a new dataset linking infant 
death certificates to parental characteristics to estimate the causal impact of Northern migration on infant mortality. The new dataset allows us to partially control for selection into migration. The results add a new dimension to the literature on the contribution of the Great Migration to the secular gains in health and income of African Americans during the twentieth century.

Katherine Eriksson, California Polytechnic University, and Gregory Niemesh, Miami University

\section{SESSION 5: MIGRATION AND IMMIGRATION}

\section{Migrant Self-Selection: Anthropometric Evidence from the Mass Migration of Italians to the United States, 1907-1925}

We study immigrant self-selection using data on Italians entering the United States between 1907 and 1925. Exploiting the relationship between average stature and living standards, we test for self-selection by comparing the heights of migrants to the height distributions of their respective birth cohorts and provinces of origin. We find that the average Italian immigrant was shorter than the average Italian of the same birth cohort-suggesting negative self-selection at the national level-but taller than the average Italian of the same birth cohort and province of origin-indicating positive self-selection at the local level.

YANNAy SPITZER, Brown University, and ArIEll Zimran, Northwestern University

\section{Cultural Assimilation in the Age of Mass Migration}

We explore cultural assimilation in the United States during the Age of Mass Migration through an analysis of immigrants' naming practices. On average, immigrant parents chose less foreign-sounding names for sons later in the birth order; no such pattern is found for daughters, sons born abroad or sons of native-born parents. This metric reveals tremendous variation in cultural assimilation: German, Russian, and Scandinavian immigrants start with distinctive naming practices and exhibit nearcomplete convergence with natives, while Italian and Irish immigrants retain distinctive names throughout this period. Men given foreign names earned less than comparable sons of immigrants parents.

\section{Leah Boustan, University of California, Los Angeles,} and RAn Abramitzky, Stanford University

Does Labor Migration Affect Human Capital in the Long Run?

Evidence from Malawi

Little evidence exists on the effects of labor migration in Africa on sending regions. We estimate the effect of labor migration on educational attainment in Malawi. We use proximity to mine recruiting stations to capture spatial variation in exposure to the 
expansion and contraction of foreign employment in South Africa in 1967 and 1974. We compare differences in educational attainment across high and low migration shock areas, and among cohorts eligible and ineligible for primary school. Age eligible cohorts have 5-7 percent more schooling in adulthood and are 2.7 to 4 percentage points more likely to have ever attended school.

Tary Dinkelman, Dartmouth College, and Martine MariotTi, Australian National University

SESSION 6: POLITICAL ECONOMY: EUROPE

\section{Taxes, National Identity, and Nation Building: Evidence from France}

This paper argues that increased state capacity can lower the collective action costs of creating well-functioning national institutions by facilitating the formation of a common identity. This hypothesis is tested by exploiting the fact that the French Monarchy was more successful in substituting its fiscal institutions for those of the medieval seigneurial regime within an area of the country known as the Cinq Grosses Fermes (CGF). Highly disaggregated data from the 1789 Cahiers de Doléances confirm that regions just inside the CGF were more likely than regions just outside the CGF to self-identify with national as opposed to local institutions.

Noel Johnson, George Mason University

\section{Archomania: Venality and Private Finances on the Eve of the French Revolution}

Venality of public office was a widespread form of rent-seeking in pre-revolutionary France. Successive legal adjustments converted venal offices into a regular form of property. Though legitimized, the practice became increasingly indefensible as a public vice for private benefit. This paper concentrates on the impact of a tax experiment on the institution 20 years prior to the Revolution. The tax in question (centième) was structured as a revelation mechanism of the value of the offices to their holders. We use a large cross-section of tax payments to infer officeholders' expectations about the survival of venality.

Rui Pedro Esteves, University of Oxford

\section{Military Conflict and the Economic Rise of Urban Europe}

We present new city-level evidence about the military origins of Europe's economic backbone, the prosperous urban belt that runs from the Low Countries to northern Italy. Military conflict was a defining feature of pre-industrial Europe. The destructive effects of warfare were worse in the countryside, leading rural inhabitants under the threat of conflict to relocate behind urban fortifications. Conflict-related city population growth in turn had long-run economic consequences. We construct a novel conflict exposure measure that computes city distances from 231 major conflicts from 1300 to 1799 . We find a significant, positive, and robust relationship between conflict exposure and 
historical city population growth. Next, we use luminosity data to construct a novel measure of current city-level economic activity. We show evidence that the economic legacy of historical conflict exposure endures to the present day.

Mark DinceCco, University of Michigan, and

Massimiliano Gaetano Onorato, IMT Lucca

\section{SESSION 7: POLITICAL ECONOMY: LATIN AMERICA}

\section{Perspiration and Inspiration: Two Centuries of Chilean Growth in Perspective}

Input availability and overall efficiency are seen as the direct determinants of output and we develop yearly growth accounting estimates for Chile extending over the nineteenth and twentieth centuries. Results are compared with a benchmark based on growth accounting estimates obtained from the literature, where the selection criteria include three aspects: year-to-year estimates, equivalent factor definitions, and a time span of at least 150 years. Due to these restrictions the benchmark turns out to be mainly a sample of today's developed countries. The main findings are: (1) In the long run, Chilean TFP contribution to GDP growth is significantly lower than the benchmark experience. This result has been already pointed out by the literature for the second half of the twentieth century and now we can see that the difference persists over time; (2) Concentrating directly on TFP growth instead of its contribution enriches the overall impression obtained from the growth accounting breakdown; (3) Weighted factor contribution is significantly higher than most benchmark countries, underscoring the significance of perspiration in Chile's growth process; and (4) Chilean TFP growth and contribution are highly volatile both over time and compared to the benchmark. Besides providing estimates stretching back until the early nineteenth century, a time period scarcely documented for emerging economies, the paper stresses the presence of volatility and discontinuities in the long-run growth path.

Jose Diaz, Pontificia Universidad Católica de Chile, and Gert Wagner, Pontificia Universidad Católica de Chile

\section{Office-Selling, Corruption and Long-Term Development in Peru}

This paper investigates the private returns to colonial offices and how these affect long-term economic and political outcomes across sub-national provinces in Peru. To estimate the private returns to office I use a unique dataset of the prices at which colonial government positions were auctioned off by the Spanish Crown between 1674 and 1751 . I first show how the gap between the prices paid for office and expected wages is significantly larger in provinces with greater access to rents from agricultural, commercial, and exploitative activities, thus consistent with extractive activities offering greater returns to political office. I then present evidence demonstrating that the gap between prices and wages is associated with a long-term economic downturn: places offering greater side gains from office in the eighteenth century today have higher poverty rates, lower public good provision, and lower household consumption. Bootstrap estimates confirm that while the variation in office prices driven by "fundamentals" is associated with better 
economic outcomes today, the residual variation in prices (potentially associated with corruption) leads to worse development outcomes today. I then argue that one reason for such reversal is political conflict: provinces in which offices offered higher returns exhibited frequent anti-colonial rebellions and heightened anti-government violence detrimental to growth. These results suggest that the motivation for accessing political office can have lasting negative consequences for economic and political development.

Jenny Guardado, New York University

\section{The Colony Strikes Back: The Case of Colombia, Jersey Standard, and the} United States

Why do empires subsidize home firms to enter into their colonies? We examine entry of Jersey Standard (JS) to Colombia. Using archival and econometric analysis we document that (1) U.S. support to Panama's secession from Colombia in 1903 created an unlikely political asset for U.S. firms entering Colombia, (2) Colombia's government induced JS to organize a coalition within the U.S. senate to compensate Colombia for Panama's loss, and (3) United States was better off facilitating JS entry. Compensation was an implicit subsidy for JS to open Colombian oilfields, induced by Colombia, and the outcome of redistributive conflict within the empire.

Xavier Duran, London School of Economics

SESSION 8: TRADE

Technology and Geography in the Second Industrial Revolution: New Evidence from the Margins of Trade

Between 1890 and 1910 Belgium experienced a trade boom. Productivity growth showed a more modest acceleration. Using a new, highly disaggregated data set on exports and imports, we introduce geography, or trade costs, as a factor in Belgium's trade performance and study its relation to industry-level productivity growth. The effect of trade costs was mediated by the extensive and intensive margins of trade. In markets for differentiated goods, the extensive margin dominated, the number of new goods and new markets expanding as trade costs fell. But the same decline in trade costs enabled less productive concerns to become viable exporters, average industry productivity stagnating as a result.

Christopher MeIssner, University of California, Davis and NBER, Michael Huberman, Université de Montréal, and Kim OOSTERLINCK, Université Libre de Bruxelles

Women Voters and Trade Protectionism in the Interwar Years

This paper explores the impact of the extensions of the franchise that followed the First World War and their effects on the political economy of trade policy. Public opinion survey evidence from the interwar years suggests that women were 
more likely to hold protectionist attitudes than men, in line with the gender gap apparent from modern day surveys. A panel data analysis of average tariff rates during the interwar period reveals an important effect of the granting of a political voice to women. Where women were entitled to vote tariffs were, on average, higher.

Alan de Bromhead, Mansfield College, University of Oxford

\section{Trade Globalization: 1827-2012 When Did Trade Costs Start to Fall?}

This article provides the first assessment of the early nineteenth century trade globalization based on a systematic collection of the available bilateral trade data. Drawing on a unique dataset of more than 1.3 million observations for the 1827-2012 period, we show that the nineteenth century trade globalization began roughly 20 years before the 1860s blooming age of trade liberalization. To do so, we use the Head and Ries (2001) index that measures for each country pair and year the implicit tariff-equivalent trade costs, relative to domestic trade costs. We develop a new method of aggregation to obtain two trade cost indices that reflect the trend for the entire sample. Our finding of an early start for the First globalization is consistent with the price convergence approach, but challenges the studies that suggest that the First globalization began c.1870. We then decompose trade costs into a border and a distance effect. We find a dramatic rise in the distance effect in the postWorld War II era. For the nineteenth century, we show a similar rise in the trade response to distance until c.1890, followed by a period of stability until World War I and a fall during the interwar de-globalization. These results show that both periods of trade globalization have been primarily fueled by the intensification of short-haul trade.

Michel FouQuin, CEPII, and Jules Hugot, CEPII

\section{SESSION 9: DIVERGING AND CONVERGING}

\section{Did Purchasing Power Parity Hold in Medieval Europe?}

This paper employs a hand-collected dataset of real exchange rates for five major currencies to consider whether the law of one price and purchasing power parity held in medieval Europe. Using single series and panel unit root and stationarity tests, we show that PPP held for several of the individual series and almost all of the panel groups. This provides further evidence for economic and financial development during the Middle Ages. Interestingly, there seems to have been greater integration along a North-South axis from London, through Bruges to Florence than there was East-West between the latter two places and Paris/Barcelona.

AdRIAN Bell, University of Reading, Chris BRoOKs, University of Reading, and TONy MOORE, University of Reading 


\section{Unified China and Divided Europe}

This paper studies the causes and consequences of political centralization and fragmentation in China and Europe. We argue that the severe and unidirectional threat of external invasion fostered political centralization in China while Europe faced a wider variety of moderate external threats and remained politically fragmented. Our model allows us to explore the consequences of political centralization and fragmentation. Political centralization in China led to lower taxation and hence faster population growth during peacetime than in Europe. But it also meant that China was relatively fragile in the event of an external invasion. Our results are consistent with historical evidence of violent conflicts, tax levels, and population growth in both China and Europe.

Chiu Yu Ko, National University of Singapore,

Mark Koyama, George Mason University, and Tuan-Hwee Sng, National University of Singapore

\section{China, Europe, and the Great Divergence: A Study in Historical National Accounting}

GDP is estimated for China between the late tenth and mid-nineteenth centuries, and combined with population estimates. Chinese GDP per capita was highest during the Northern Song dynasty and declined during the Ming and Qing dynasties. China led the world in living standards during the Northern Song dynasty, but had fallen behind Italy by 1300 . At this stage, it is possible that the Yangzi delta was still on a par with the richest parts of Europe, but by 1700 the gap was too large to be bridged by regional variation within China and the Great Divergence had already begun.

Stephen Broadberry, London School of Economics and CAGE, Hanhu Guan, Peking University, and David Daoku Li, Tsinghua University

\section{SESSION 10: POLITICAL ECONOMY: AMERICAN STATES AND TRIBES}

\section{How Much Does Political Uncertainty Matter? The Case of Louisiana Under Huey Long}

We study the role of political uncertainty in economic outcomes for the case of Huey Long's reign over Louisiana during the Great Depression. We construct two established measures of uncertainty specifically for Louisiana using primary sources: stock price volatility and newspaper mentions of the word "uncertainty." Combining these uncertainty measures with employment data from the Census of Manufactures, we attempt to identify the effects of political uncertainty in Louisiana using the state of Mississippi as a control group. We find limited evidence for the significance of political uncertainty using a standard diff-in-diff framework. This is true even after restricting attention to border counties. Finally, we conduct an event study on the unexpected assassination of Long in September 1935. Again we find no effect on 
employment even though there is some narrative evidence for a decline in political uncertainty. We conclude that whatever political uncertainty was attributable to Huey Long mattered very little for economic outcomes.

Gabriel Mathy, American University, and Nicolas Ziebarth, University of Iowa and NBER

The Persistence of De Facto Power: Elites and Economic Development in the U.S. South, 1840-1960

Wealthy elites may end up retarding economic development for their own interests. This paper examines how the historical planter elite of the Southern United States affected economic development at the county level between 1840 and 1960. To capture the planter elite's potential to exercise de facto power, I construct a new dataset on the personal wealth of the richest Southern planters before the American Civil War. I find that counties with a relatively wealthier planter elite before the Civil War performed significantly worse in the post-war decades and even after World War II. I argue that this is the likely consequence of the planter elite's lack of support for mass schooling. My results suggest that when during Reconstruction the U.S. government abolished slavery and enfranchised the freedmen, the planter elite used their de facto power to maintain their influence over the political system and preserve a plantation economy based on low-skilled labor. In fact, I find that the planter elite was better able to sustain land prices and the production of plantation crops during Reconstruction in counties where they had more de facto power.

Philipp Ager, University of Southern Denmark

The Indian Reorganization Act, Tribal Sovereignty, and Economic Development

In 1934 the U.S. government passed significant legislation governing American Indian reservations, the Indian Reorganization Act (IRA). Adoption of the IRA was voluntary and tribes declining the IRA faced less federal oversight. This paper measures the impact of IRA adoption on current reservation development. To mitigate selection concerns, I exploit IRA voting results from the mid-1930s by restricting my analysis to tribes that held close elections. Empirical results using 1990 reservation-level census data indicate that IRA adoption stifled economic development. Per capita income is more than 40 percent lower among IRA reservations. The results indicate increased self-governance is necessary for development on Indian reservations.

Dustin FrYe, University of Colorado, Boulder

\author{
SESSION 11: HOW NEW EVIDENCE AND NEW INTERPRETATIONS \\ ARE CHANGING OUR UNDERSTANDING OF THE ANCIENT WORLD
}

Leagues and Kingdoms. Beyond the City-State

This paper examines the impact of the new political economies of the Hellenistic kingdoms, treating the new economic and fiscal institutions that were created, and the resulting change in the behavior both of states and of individuals. I will examine in 
particular the spread of "associations" and other private social organizations. While such groups were hardly new in the Hellenistic period, I will examine the relationship between them and the new kingdoms, and specifically the important role that such organizations played in private agreements between persons as well as in trade networks.

Joseph Manning, Yale University

\section{People and Cities: Economic Horizons Beyond the Hellenistic Polis}

A human glue bonded the Hellenistic world together. People moved beyond the polis and existed within and out with the city. The complex and changing environment of monarchies and the growing Roman Republic made the Hellenistic period a time of dynamic change. But ever present throughout was the polis whose persistence from Archaic, through Classical, and Hellenistic eras presents a unique opportunity to read political economies in the long run. This paper offers an overview that looks from within and beyond the polis through its institutions and people to the horizons of the Hellenistic world at large.

Graham Oliver, Brown University

\section{Flexible Interfaces of the Hellenistic World}

The Hellenistic world was not a world without frictions, where transaction costs would have miraculously absent. But the existence of a common language and cultural background, of striking similarities in the border crossing procedures, of a common currency for international trade as well as on the whole low customs duties allowed men, goods, and ideas to circulate with on an unprecedented scale and with unprecedented speed in the Mediterranean basin and beyond. In a world where cities remained the nodes of international communications, local associations of traders played a prominent interface role at the junction between international and local market.

Alain Bresson, University of Chicago

\section{SESSION 12: CORPORATIONS}

\section{The Labor Market Consequences of Electricity Adoption in the Concrete Industry During the Great Depression}

The 1920s and 1930s witnessed changes in the U.S. labor market, with a shift away from dexterity-intensive occupations, a productivity speedup, and low job creation. This paper asks whether the adoption of electricity can explain these changes. The identification strategy uses a state's initial loading on the technology to generate electricityhydroelectric power or coal power-as an instrument for changes in the price of electricity. It also uses a newly digitized dataset for the concrete industry from 1929 to 1935 to provide plant-level measures of labor market outcomes. Technical progress in electric utilities caused, in the downstream industry of concrete, a decrease in employment and in the labor share of income, as well as an increase in labor quantity productivity and electrical intensity. 


\section{Factory Productivity and the Concession System of Incorporation in Late Imperial Russia}

In the Russian Empire, incorporation required a time-consuming and expensive Imperial concession, yet more than four thousand Russian firms incorporated before 1914. This paper documents the characteristics of incorporating firms by examining a novel panel database of manufacturing enterprises from Russian factory censuses conducted in 1894, 1900, and 1908. In the cross-section, corporation-owned factories are larger and more productive. When factories are matched across years, more productive factories are more likely to incorporate; after incorporating, these factories have greater machine power per worker and even greater revenue per worker, suggesting the importance of incorporation for capital accumulation.

Amanda Gregg, Yale University

\section{The London Water Supply Industry and the Industrial Revolution}

The history of London's water supply industry in the eighteenth century has relevance for the history of the Industrial Revolution. Established around 1600, companies were supplying water directly to tens of thousands of houses by 1700 and continued to grow thereafter. This water supply was anomalous as compared to other cities in Europe, which were much smaller. The industry developed in Britain in part due London's status as a commercial hub and the willingness of both local and national government to support the project. Joint-stock financing was important for water companies. Finally, this history shows the existence of technological inventiveness outside the manufacturing sectors.

LesLie TOMORY, McGill University

\section{SESSION 13: PRIESTS, WAR, AND PROPERTY}

Fighting Against Democracy: Military Factions in the Second Spanish Republic and Civil War (1931-1939)

My paper studies the failure to consolidate democracy in Spain during the Second Republic (1931-1939). Existing explanations rely on "block views" in which major players are treated as homogenous groups. In contrast, I focus on the Army and show that the military was a heterogeneous political player. I build a new data set to estimate how republican military reforms related to officers' likelihood to support the rebel coup that ended the Republic. Results indicate that the Army was not a monolithic organization. Officers and factions whose professional and economic prospects deteriorated under the Republic were more likely to revolt.

Alvaro La Parra Perez, University of Maryland

\section{Theocracy over Time}

Political authorities have historically had a mysterious tendency towards theocracy, exemplified by their religious titles, close affiliations with religious figures, or even divine powers. To examine theocracy over time, we constructed two unique datasets, one that includes information on the political and religious characteristics of more 
than five hundred polities observed in history and another that uses today's nations as units of analysis and tracks in 50-100 year intervals which polities have ruled in these lands. Combining the information from the two datasets, we examine the evolution of theocracy over time and its variation across geographic regions and religious traditions.

Metin Cosgel, University of Connecticut, and Thomas Miceli, University of Connecticut

Property Rights, Land Markets, and Land Use in Bangkok: Consequences of Siam's 1901 Land Act

This paper assesses the impact of Siam's 1901 Land Act on land markets and land use in Bangkok. Using a sample of orchard title deeds issued in the 1880s, this study investigates the incidence of land transfers and subsequent land use patterns both before and after the transition from usufruct to full private ownership rights as a result of the 1901 Act. Survival analysis shows that introducing full private property rights led to an acceleration of urban orchard title transfers. In addition, qualitative analysis suggests that institutional change facilitated land use diversification away from agriculture and towards alternative economic activities.

Jessica Vechbanyongratana, Chulalongkorn University

SESSION 14: EDUCATION

\section{Research Proximity and Productivity: Long-Term Evidence from Agriculture}

We use the late nineteenth century establishment of agricultural experiment stations in the United States to estimate the importance of proximity to research for productivity growth. Our analysis of county-level agricultural census data from 1870 to 2000 reveals three results. First, research proximity effects from permanent station opening grew for about 20 years and then subsequently declined until becoming largely absent today. Second, proximity to station-based innovations affected local farmers' productivity for 20 to 40 years after the discovery. Third, research proximity effects remain today where stations historically focused on basic research and where nearby farmers were producing with frontier technology.

Shawn Kantor, Rensselaer Polytechnic Institute and NBER, and Alexander Whalley, University of California, Merced and NBER

Government-Led Innovation in a Period of Small Government: The United States, 1820 to 1941

In conventional interpretations, U.S. technological innovation was overwhelmingly private before 1941. Building on studies of biological and mineral innovation, I utilize historical biographies to contend that from 1820 through 1941, the government targeted, structured, and undertook technological innovations across wide ranges of the economy. 
Fifty-six percent of 1,336 major innovators learned from government employment and contracting in ways that shaped their innovations. State and local governments were almost active as the federal government. Such innovation concentrated in civilian uses. Studies of the USDA, the USGS, urban water-supply agencies, and land-grant colleges reveal how small government generated so much innovation.

Ross Thomson, University of Vermont

\section{SESSION 15: SOMETHING BLUE}

Fiscal Sustainability and the Value of Money: Lessons from the British Paper Pound, 1797-1821

This article explores the determinants of price level fluctuations in Britain during the first suspension of the gold standard over the 1797-1821 period. I find that the contemporary price level was determined by world gold prices and expectations regarding the resumption of the gold standard at the pre-war parity. As the latter hinged on market participants' expectations concerning the financial burden of the Napoleonic Wars, my contribution establishes the importance of fiscal factors for the determination of the price level.

Pamfili Antipa, Banque de France

Network Effects, Homogeneous Goods and International Currency Choice: New Evidence on Oil Markets from an Older Era

Conventional wisdom has it that network effects are strong in markets for homogenous goods, leading to the dominance of one settlement currency in such markets. The alleged dominance of the U.S. dollar in global oil markets is said to epitomize this phenomenon. We question this presumption with evidence for earlier periods showing that several national currencies have simultaneously played substantial roles in global oil markets. That several national currencies could simultaneously play a role in international oil settlements suggests that a shift from the current dollar-based system toward a multipolar system in the period ahead is not impossible.

BARry EICHENGREen, University of California, Berkeley, Livia Chițu, European Central Bank, and Arnaud Mehl, Paris School of Economics

\section{Human Capital on the High Seas - Job Mobility and Returns to Technical Skill During Industrialization}

This paper examines the effects of engineer-oriented and technical experience on job mobility during the late nineteenth and early twentieth centuries. We exploit longitudinal data on British and American naval officer careers to show how various types of technical experience and managerial positions affected the probability of job switches between the 1870s and early 1900s. Further, following a Topel and Ward (1992) based 
framework, we impute annual rates of return to education and technical training. To our knowledge these are the earliest estimates of returns to any type of technical skill for an advanced economy.

\section{Darrell Glaser, United States Naval Academy, and} Ahmed Rahman, United States Naval Academy

\section{SESSION 16: BORROWING AND SHOCKS}

\section{Protecting the Borrower: An Experiment in Colonial India}

We study the background and impact of the Deccan Agriculturists' Relief Act (DARA), a legislation to protect debtors that was adopted in the Bombay Presidency in colonial India. Our analysis is relevant to two literatures. To the discussion of "legal origins" of developing-country legal systems we present DARA as an example of explicit repudiation of legal importation by a British colonial state. To developing country policymakers DARA may be instructive as a credit-market intervention in which borrowers were protected from lenders (and maybe even themselves) without, apparently, hurting economic growth.

\section{Latika Chaudhary, Scripps College, and Anand Swamy, Williams College}

\section{Textiles and the Historical Emergence of Gender Equality in China}

This paper seeks to better understand the historical determinants of son preference among Han Chinese. I test the hypothesis that historical textile production led to a decline in son preference. I exploit exogenous variation in historical textile production at the county level to casually identify the effect of textiles on son preference. I find that historical textile production is positively correlated with female labor participation, and negatively correlated with sex ratio imbalances and sex-specific parental investment. I use an instrumental variable strategy to account for potential endogeneity and measurement error. My results are robust to the use of different sub-samples and propensity score matching.

Meng Xue, George Mason University

\section{7: Economic Shocks, Conflict, and the Slave Trade}

Suppression of the slave trade after 1807 increased the incidence of conflict between Africans. We use geo-coded data on African conflicts to uncover a discontinuous increase in conflict after 1807 in areas affected by the slave trade. In West Africa, the slave trade declined. This empowered interests that rivaled existing authorities, and political leaders resorted to violence in order to maintain their influence. In WestCentral and South-East Africa, slave exports increased after 1807 and were produced through violence. We validate our explanation using Southwestern Nigeria and Eastern South Africa as examples. Present-day conflict is more severe in regions where slave exports rose after 1807 . 